\title{
The Pre-Service EFL Teachers' Development of Phonological Processing and Evaluation of Their Attitudes toward Pronunciation ${ }^{1}$
}

El Desarrollo del Procesamiento Fonológico y de la Evaluación de la Actitud de Profesores en Formación de Inglés como Lengua Extranjera en Formación hacia la Pronunciación

Canan Aksakallı and Oktay Yağız ${ }^{2 *}$

Atatürk University, Turkey

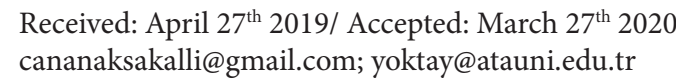




\section{Abstract}

This study aimed at investigating EFL pre-service teachers' attitudes towards pronunciation and pronunciation teaching. Another purpose was to explore the outcomes of pronunciation instruction of EFL pre-service teachers' phonological development and, based on the findings, to provide suggestions taking learners' pedagogical needs into consideration. The study was conducted using a quantitative research design. 107 EFL pre-service teachers participated in the phase of questionnaire responding of the study, while 86 of whom participated in the interventional phase of the study. For fourteen weeks, one of the researchers provided EFL preservice teachers with pronunciation instruction focusing on segmental and suprasegmental features in English pronunciation. The results revealed that the participants had generally positive attitudes toward proper pronunciation in target language, which means that participants agreed upon the importance of pronunciation in target language and perceive pronunciation as a vital component of language learning and teaching. As to the interventional findings, it was found that the participants displayed significant improvement in articulation of vowels and consonants. In addition, the present study also found out that the participants' post-test scores at the suprasegmental level (word-stress, intonation comprehensibility) were significantly higher than their pre-test scores.

Key Words: second language; English pronunciation; L2 pronunciation; pronunciation education; teaching segmentals; teaching suprasegmentals; phonological improvement; attitudes; EFL pre-service teachers.

\section{Resumen}

Este studio tiene como propósito investigar las actitudes hacia la pronunciación y la enseñanza de pronunciación de los profesores de inglés como lengua extranjera en formación. Otro propósito era explorar los resultados de la instrucción de pronunciación sobre el desarrollo fonológico de los profesores y, basado en los resultados, proporcionar sugerencias al tener en cuenta las necesidades pedagógicas de los aprendices en consideración dentro de la investigación. El estudio fue desarrollado usando un diseño de investigación cuantitativa. 107 profesores de inglés como lengua extranjera en formación participaron en la fase de respuesta al cuestionario, mientras que 86 de los cuales participaron en la fase de intervención del estudio. Por catorce semanas, uno de los investigadores proporcionó a los profesores en formación una instrucción sobre características segmentales y suprasegmentales en la pronunciación de inglés. Los resultados revelaron que la participación tuvo actitudes positivas hacia la apropiada pronunciación en la lengua objetivo, lo que significa que los participantes acordaron sobre su importancia y lo percibieron como un componente vital del aprendizaje y enseñanza del idioma.

Finalmente, los resultados demostraron que los participantes tuvieron una mejoría significativa en la articulación de vocales y consonantes. Además, el presente estudio también encontró que los puntajes de pruebas posteriores sobre el nivel suprasegmental (estrés de la palabra, comprensibilidad de la entonación) fueron significativemente más altos que en la prueba inicial. 
Palabras clave: Segunda lengua; pronunciación en inglés; pronunciación de segunda lengua; enseñanza de segmentales; enseñanza de suprasegmentales, mejoría fonológica, actitutes, profesores de inglés como lengua extranjera en formación.

\section{Resumo}

Este estudo tem como propósito pesquisar as atitudes em relação à pronúncia e ao ensino da pronúncia dos professores de inglês como língua estrangeira em formação. Outro propósito era explorar os resultados da instrução de pronúncia sobre o desenvolvimento fonológico dos professores e, baseado nos resultados, proporcionar sugestões ao levar em consideração as necessidades pedagógicas dos aprendizes em questão dentro da pesquisa. $\mathrm{O}$ estudo foi desenvolvido usando um desenho de pesquisa quantitativa. 107 professores de inglês como língua estrangeira em formação participaram na fase de resposta ao questionário, enquanto que 86 dos quais participaram na fase de intervenção do estudo. Por catorze semanas, um dos pesquisadores proporcionou aos professores em formação uma instrução sobre características segmentais e suprassegmentais na pronúncia de inglês. Os resultados revelaram que a participação teve atitudes positivas em relação à apropriada pronúncia na língua objetivo, o que significa que os participantes acordaram sobre sua importância e o perceberam como um componente vital da aprendizagem e ensino do idioma. Finalmente, os resultados demonstraram que os participantes tiveram uma melhoria significativa na articulação de vocais e consonantes. Além disso, o presente estudo também encontrou que as pontuações de provas posteriores sobre o nível suprassegmental (estresse da palavra, compreensibilidade da entonação) foram significativamente mais alto que na prova inicial.

Palavras chave: Segunda língua; pronúncia em inglês; pronúncia de segunda língua; ensino de segmentais; ensino de suprassegmentais; melhoria fonológica; atitudes; professores de inglês como língua estrangeira em formação. 


\section{Introduction}

М ith the advent of communicative language teaching (CLT), intelligible communication has been attracting renewed attention within the field of second and foreign language teaching, and pronunciation has begun to be recognized as one of the most crucial aspects of intelligible communication (Alastuey, 2013; Elias, 2000; Levis, 2005; Munro \& Derwing, 1999; Sifakis, 2014). A basic level of pronunciation is required for effective communication and for preventing comprehension problems, misunderstandings and communication breakdowns (Roccamo, 2015). In case of inadequate phonological skills, learners might be judged by listeners negatively in terms of their overall language ability as well (Gilakjani \& Sabouri, 2016). Similarly, pronunciation is highly related to prestige and plays an important part in social interactions. From a sociolinguistic standpoint, good pronunciation prevents learners from being recognized as foreigners (Lord, 2008) and promotes learners' group identity (Gatbonton, Torfimovich \& Magid, 2005). Every human being wants to belong to a particular group to be able to have similar worldviews and behavioral norms. In such a situation, L2 accent can be considered as an indicator of a learners' degree of ethnic affiliation. Due to insufficient empirical research into pronunciation within the field of applied linguistics, many teachers remain skeptical about the integration of pronunciation into language classrooms and pay little attention to pronunciation teaching (Derwing \& Munro, 2005). Having identified teachers' tendency toward the integration of pronunciation into language classrooms, Derwing and Munro (2005) made an appeal for more extensive research into pronunciation to improve pronunciation researchers', language learners' and teachers' knowledge of the nature of pronunciation and its impacts on communication as well as social identity and linguistic competence.

By investigating EFL pre-service teachers' attitudes toward pronunciation and pronunciation teaching as well as the impacts of pronunciation instruction on their pronunciation skills and phonological awareness, this study may shed more light on the issues of English pronunciation in Turkish EFL context. The rationale of the study is mainly based on the notion that little attention has been paid to pronunciation in language teaching process. To fully understand the nature of issues regarding pronunciation in Turkish EFL context, further investigation into pronunciation teaching is required. Therefore, this study may provide a further understanding of pronunciation teaching in language teaching programs in terms of different population and setting. 


\section{Literature Review}

In many EFL/ESL settings, compared to the language skills such as grammar, reading or vocabulary which are taught individually, language teachers may neglect pronunciation and consider that it should be taught in higher levels. Much of the research dedicated to pronunciation teaching has indicated that pronunciation is regarded as the "Cinderella" of language teaching (Kelly, 1969, p. 87) since linguists and philologists have paid attention to other aspects of language more than to pronunciation. Despite this fact, its crucial role in intelligible communication has led researchers to investigate pronunciation instruction from different perspectives such as goals, priorities, challenges and needs in the field of pronunciation teaching.

Pronunciation in the second language gives a clear idea of language ability to encompass the differentiation from the production of sounds. This framework includes the segmental and suprasegmental levels. While the segmental frame is more effective in the area of accent, the suprasegmental frame forms an important element of oral communication such as stress, rhythm and intonation as well as intelligibility, fluency and naturalness in pronunciation. These two important elements in pronunciation are a must for healthy communication. (Hinofotis \& Bailey, 1980) While inaccurate pronunciation at the individual sounds are often compensated provided that intelligibility is ensured, it may result in significant problems in some cases due to lexical confusion or lack of differentiation (Wilner, 2007; Labov \& Hanau, 2011). The potential of miscommunication due to segmental errors meanwhile may cause discomfort (Fayer \& Krasinski, 1987) and tendency to stop the communication (Singleton, 1995). Suprasegmental (i.e. stress, rhythm, intonation) features are other speech components, which affect intelligibility, which Munro et al. (2006, p.112) defines as "the extent to which a speaker's utterance is actually understood".

However, Derwing and Munro (2015) highlight that recent years, practice and research have considerably focused on intelligibility rather than accent related issue. They attribute this intelligibility priority over accent-based approach to the fact that few L2 speakers can achieve native-like pronunciation in another language. Isaac and Trofimovich (2012) likewise state that L2 speakers' intelligibility achievement is more important than sounding nativelike without accent. However, though intelligibility and accentedness are partially independent (Derwing \& Munro, 1997; Munro \& Derwing, 1995) both phenomena are closely related. Therefore, these segmental and suprasegmental features of a language may be an effective instructional instrument through a cognitive function. Educational support is one of the variables which affect L2 learners' cognitive attainment in pronunciation (Saito, 2015a)

Given the influence of age (Saito, 2015b), amount of L2 exposure (Flege, 2009, Moyer, 2004), individual differences (Dörnyei, 2006), learning style (Baran-Lucarz, 2012) on L2 phonological processing, explicit learning acts a role through processing 
capabilities and long-term memory (Baddeley, 2012) it becomes a necessity particularly for the late language learners (Long, 2015). Research evidence has supported the effectiveness and functionality of pronunciation instruction with a form-focused on L2 learners' pronunciation improvement (e.g. DeKeyser, 2003; Derwing \& Munro, 2005; Derwing, Munro, Foote, Waugh, \& Fleming, 2014).

Learning and achievement are affected by psychological variables in many areas of language. Pronunciation is one of the domains in which attitudes and beliefs determine learning choices, priorities and perceptions. Affective variables such as motivation and attitude can affect L2 pronunciation attainment (Tsunemoto \& McDonough, 2020). Individuals with positive attitudes towards the importance of accurate pronunciation displayed better profiles of L2 users (Huensch \& Thompson, 2017). Besides, confident L2 speakers can show positive attitudes towards pronunciation learning (Uchida \& Sugimoto, 2019). Gained positive attitudes meanwhile can lead to less anxiety to pronounce better and improve current proficiency (Sardegna, Lee, \& Kusey, 2018).

The efficacy of pronunciation instruction, either explicit or implicit, is one of the most salient issues examined within the field of pronunciation teaching. Although there were very few studies related to the effectiveness of pronunciation instruction until the 1960s; with the appearance of new language teaching approaches and a wide range of researchers emphasizing the importance of pronunciation instruction, the tendency has changed and pronunciation has become a research topic (Yağ1Z, 2018). At the turn of 21st century, much more emphasis was placed on the effectiveness of pronunciation instruction. Various studies provide evidence supporting that there is a positive correlation between pronunciation proficiency and pronunciation instruction. (Arrieta, 2017; Camus-Oyarzun, 2016; Chiba, 2012; Couper, 2003; Derwing \& Munro, 2005; Elliott, 1995; Huthaily, 2008; Kissling, 2015; Roccamo, 2015; Thomson \& Derwing, 2014; Tlazalo Tejeda \& Basurta Santos, 2014; Zamora, 2015).

There appears to be a clear consensus among pronunciation researchers that pronunciation is worth mentioning within the field of language teaching. To give an example, Couper (2003) examined the efficacy of explicit pronunciation teaching by conducting an experimental study and the findings of the pre- and post-tests revealed a clear improvement in learners' pronunciation accuracy on the reading and speaking tasks undertaken in the study. Saito (2012) also emphasized the value of pronunciation instruction on pronunciation skills of language learners. Investigating impacts of instruction on L2 pronunciation development through a research synthesis of 15 quasi-experimental studies, Saito (2012) provided results referring to the positive effects of instruction on both improving segmental and suprasegmental aspects of pronunciation and enhancing perceived comprehensibility. Bringing the biological and pedagogical variables to the forefront in the acquisition of phonology, Elliott (1995) carried out a study on the effects of formal instruction in pronunciation. The 
analysis of the data showed that pronunciation instruction had positive effects on learners' accuracy of pronunciation.

Based on the findings of the studies mentioned above, it seems clear that even devoting only a relatively little time to pronunciation teaching in language classrooms can lead to beneficial results in learners' perception and production skills. Thus, teachers can diagnose students' pronunciation difficulties, raise their awareness of pronunciation and enable them to practice pronunciation patterns and observe their own learning process.

Some studies, on the other hand, provide counterevidence that there is not a close relationship between pronunciation instruction and phonological competence (Ducate \& Lomicka, 2009; Harris, 2002; Kennedy, 2008; Kissling, 2013). The explanations for this may be learner differences, instructional focus, aims, type and duration of instruction given and assessment procedures (Thomson \& Derwing, 2014). To give an example, Harris (2002) supports that pronunciation improvement occurs resulting from exposure to target language rather than explicit formal instruction on pronunciation. Similarly, Kennedy (2008) suggests that pronunciation training based on prosodic features may not always lead to positive changes in intelligibility and pronunciation.

Given the controversial ideas regarding the effectiveness of pronunciation training in the relevant literature, it can be deduced that there is still a need for exploring the issues of pronunciation in language teaching. Since pronunciation teaching has regained its status in improving general language competence, this notion should be investigated in terms of different perspectives to increase language learners' phonological awareness and improvement as well as general language skills.

\section{Research questions}

1. What are the attitudes of pre-service teachers of English language toward pronunciation and pronunciation instruction?

2. To what degree is the pronunciation instruction effective on pre-service English teachers' segmental and suprasegmental domains of L2 oral proficiency? 


\section{Methodology}

\section{Research Design}

In this study, a quantitative research design was used. Quantitative research designs can be classified into two major categories: experimental and non-experimental research designs. An experimental study was conducted because in experimental studies "researchers seek to test whether an educational practice or idea makes a difference for individuals" (Creswell, 2014). This study tried to determine the effect of pronunciation instruction (independent variable) on production skills (dependent variables) implementing an intervention. In other words, an experimental design was the most appropriate way to identify a cause-effect relation. Experimental research designs are divided into two main groups: strong experimental research designs and weak experimental designs which are also identified as quasi-experimental design.

Among types of quasi-experimental designs, one-group pretest-posttest design was used in this study. Although a lack of some type of comparison is considered as a negative factor, this design is widely used in educational research (Campbell \& Stanley, 2015).

A pretest $(\mathrm{O} 1)$ is administered to a single group of participants before giving an experimental treatment condition (X). The posttest $(\mathrm{O} 2)$ is then implemented. The difference between pretest and posttest is interpreted as an indicator of the effectiveness of treatment condition. The weakness of one-group pretest-posttest research design is that extraneous variables including history, maturation, instrumentation and regression artifacts may influence posttest results. As such, the difference between pretest and posttest may not be completely attributed to an independent variable, which makes it a weak design. To minimize this weakness and potential threats, the researchers employed "The Pronunciation Attitude Inventory" (Elliott,1993) as a quantitatively descriptive tool at the end of the intervention.

\section{Participants}

107 undergraduate students participated in this study. The participants' ages ranged in from 18 to 20 and were in the first year of their four-year degree program in the English language teaching department at a state university. This department was selected since the students were prospective teachers of English who have considerable enthusiasm to learn more and develop their linguistic competency in English. Given the entry requirements for EFL departments, it can be considered that their proficiency levels in English were of upper-intermediate and pre-advanced level. It should be noted that in questionnaires related to the participants' attitudes toward pronunciation, it was decided to use pseudonyms to comply with ethics in quantitative research. 


\section{Pronunciation attitude inventory}

With the aim of collecting quantitative data of the study about pre-service EFL teachers' attitudes toward pronunciation, "The Pronunciation Attitude Inventory" was implemented. The inventory originally developed by Elliott (1993) and adapted by Roccamo (2015) was the most commonly used data collection instrument in the studies investigating language learners' attitudes toward pronunciation of target language. The last two items of the inventory used by Roccamo were dropped out of the inventory used in the present study for the reason that they were open-ended questions, and, thus, the removal of these items would not influence the validity and reliability of the instrument. The present inventory includes 13 statements about pronunciation and it was designed in the form of five-point Likert scale ranging from "always and almost always true of me" to "never and almost never true of me".

\section{The rubric}

A pronunciation rubric was used to assess learners' performances in reading aloud recordings obtained through the pre-test and post-test. To adapt a rubric suitable for the purposes of the current study, the relevant literature was examined and all the similar rubrics were found and evaluated in terms of the content, aim and categories they had. Taking the aims and research questions of the present study into consideration, a rubric was adapted using the rubric developed by Ma (2015) and including 6 categories. However, two categories -rhythm and sentence stress- were dropped out of the present rubric because only intonation and word-stress were taught in pronunciation classes. Also, comprehensible speech was among the issues taken into account and discussed in the present study, and, thus, it was aimed at exploring how the pronunciation instruction would affect the participants' comprehensibility. Therefore, the category of comprehensibility was added into the rubric as the fifth category. For the purpose of ensuring whether or not the rubric adapted as a first draft was appropriate to use in the study, a rubric assessment tool was developed. To ask for their comments on the rubric adapted, this tool was sent to 5 language instructors who were experts in their profession and had adequate knowledge of English pronunciation. The language instructors gave feedback on the rubric. Among the instructors, there was a consensus about the rubric, which it was appropriate to be used in the study. The rubric adapted involved 5 categories including vowels, consonants, intonation, wordstress and comprehensibility.

\section{Data Collection Procedure}

Before proceeding with data collection, permission was sought from the English Language Teaching Department of Atatürk University. The administration of the 
department accepted this request and allowed the researcher to work with the firstyear classes of the department for both giving pronunciation instruction and collecting data by means of inventory, and pre-/post-tests.

Subsequent to the required permission from the department, a pretest was administered at the outset of the study to explore what the participants' levels of the use of English pronunciation at the segmental and suprasegmental levels was. The pretest included items measuring the learners' level of pronunciation competence and comprehensibility.

During the first two weeks of the semester devoted to pronunciation teaching, the participants were presented with two paragraphs extracted from a text and they were asked to read the same text in the classroom one by one. All the recordings in the study were saved using a voice recorder.

After completing the pre-test process, pronunciation instruction started and lasted for 12 weeks in the fall term. The students received a total of 36 hours of pronunciation instruction each of which included fifty-minute pronunciation lessons. The teaching syllabus included the teaching of segmental and suprasegmental features of English including the articulation of vowels and consonants as well as intonation and wordstress forms. The lessons focused on the correct articulation of English sounds by first listening and then trying to imitate on their own. After practicing the articulation of the sounds, the students reinforced these sounds using within the words. The consonants and vowels that do not exist in Turkish language were especially emphasized in lessons and practiced more with extra materials and videos to enable students to articulate them correctly. The students were encouraged to practice English sounds correctly in and out of the classroom with additional exercises. After completing the teaching of segmental features, intonation and word-stress forms and rules were provided by instructor using the examples and exercises in the book chosen for the pronunciation teaching period.

A post-test was administered at the end of the study to all the participants. This post-test included the same procedures as in the pre-test. After that, the students were informed that they would participate in a pronunciation attitude inventory.

The administration of the inventory took place at the end of the semester for enabling students to develop certain types of attitudes toward pronunciation during educational term. The participants were asked to read and respond the whole inventory in 15 minutes. 


\section{Rating Procedure}

The recorded samples gathered from the participants were rated by two raters who were native speakers of English. During the rating process, a 5-point Likert type scale was employed.

All the recordings were transferred from the voice recorder to the computer. Pretests and post-tests were sent to a different file created for each student. After that, the computer files and rating sheets were submitted to the raters to enable them to rate each recording.

Some of the recordings were excluded since they had some technical problems. For example, some students did not participate in either pretest or posttest. Likewise, there occurred some uncontrollable situations such as sudden noises in the outer environment like a motorbike or shouting people. The rest of the recordings of 86 participants were rated by the native speaker of English.

\section{Analysis}

Cronbach' Alpha reliability analysis was conducted to identify the reliability of the research instruments. The results revealed that Cronbach's Alpha reliability coefficient of the measurements obtained from the questionnaire was 0,78. A desired critical alpha value should be at least 0,70 to consider a reliability coefficient to be acceptable. In the analysis of pre-/post-tests, percent agreement of two raters was calculated for inter-rater reliability. By this way, it was found that percent agreement was $88 \%$. This means that the ratings of the raters were reliable.

SPSS 23 was used to analyze the data. A Kolmogorov-Smirnov test of normality was conducted to see whether each dependent variable was normally distributed and the results are presented in Table 1.

Table 1. Results of Kolmogorov-Smirnov Test

\begin{tabular}{|l|l|l|l|}
\hline & \multicolumn{3}{|l|}{ Kolmogorov-Smirnov $^{\mathrm{a}}$} \\
\hline & Statistic & Df & $\mathrm{P}$ \\
\hline Inventory &, 389 & 107 &, 372 \\
\hline Pre-test & .293 & 86 & .277 \\
\hline Post-test & .275 & 86 & .298 \\
\hline
\end{tabular}

a. Liliefors Significance Correction 
According to the table above, it was found that the data were normally distributed. In this respect, it can be concluded that the normality assumptions were met for all of the variables. Therefore, parametric tests were conducted to analyze the data.

After identifying the normal distribution of the data related to pre-service English language teachers' attitudes toward English pronunciation, mean and standard deviation values were presented. Reversed scoring was employed for the items 3, 9, and 13 in the questionnaire since they were negatively worded questions. In the process of interpreting mean, a scoring system was used in which the interval width of 1.001.80 showed "very low-strongly disagree", the 1.81-2.60 interval showed "low-disagree", the 2.61-3.40 interval showed "medium level-not sure", the 3.41-4.20 interval showed "high- agree", and the 4.21-5.00 interval showed "very high-strongly agree".

For the purpose of identifying the potential differences between or among the mean scores in the data set, Paired Samples t-test was adopted. As for the analysis of variance and the homogeneity of the data set, Levene's Test was used as a precondition for parametric tests such as t-test. According to the results obtained by Levene's Test, it was found that the variance of each independent variable was homogeneous.

Paired samples t-test, which is a parametric test, was adopted to examine if there was any change in the students' pronunciation. Paired samples t-test should be performed on the ratings of pre-tests and post-tests of each participant because this type of statistical test compares the means of two repeated measures for statistical significance. Pronunciation instruction provided was the independent variable while improved comprehensibility, vowels, consonants, intonation and word stress were the dependent variables.

\section{Results}

\section{Results of Pronunciation Attitude Inventory}

The mean and standard deviation values related to pre-service English teachers' attitudes toward pronunciation are shown in Table 2. 
Table 2. Mean Scores and Standard Deviation Values related to Attitudes toward Pronunciation

\begin{tabular}{|c|c|c|}
\hline$n=107$ & \multirow{2}{*}{$\nabla$} & \multirow{2}{*}{ SS } \\
\hline Items & & \\
\hline 1. I'd like to sound as native as possible when speaking English. & 3.98 & .99 \\
\hline 2. Acquiring proper pronunciation in English is important to me. & 4.31 & .85 \\
\hline 3. I will never be able to speak English with a good accent. & 4.12 & 1.12 \\
\hline 4. I believe I can improve my pronunciation skills in English. & 4.57 & .75 \\
\hline $\begin{array}{l}\text { 5. I believe more emphasis should be given to proper pronunciation } \\
\text { in class. }\end{array}$ & 3.99 & .90 \\
\hline $\begin{array}{l}\text { 6. One of my personal goals is to acquire proper pronunciation skills } \\
\text { and preferably be able to pass as a near-native speaker of the } \\
\text { language. }\end{array}$ & 4.20 & .97 \\
\hline 7. I try to imitate English speakers as much as possible. & 3.95 & 1.03 \\
\hline $\begin{array}{l}\text { 8. Communicating is much more important than sounding like a } \\
\text { native speaker of English. }\end{array}$ & 3.70 & 1.05 \\
\hline $\begin{array}{l}\text { 9. Good pronunciation skills in English are not as important as } \\
\text { learning vocabulary and grammar. }\end{array}$ & 3.79 & 1.43 \\
\hline 10. I want to improve my accent when speaking English. & 4.58 & .81 \\
\hline 11. I'm concerned with my progress in my pronunciation of English. & 3.73 & 1.28 \\
\hline 12. Sounding like a native speaker is very important to me. & 4.26 & .97 \\
\hline $\begin{array}{l}\text { 13. I do not practice a native-like accent in class because of how other } \\
\text { students in class would perceive it. }\end{array}$ & 3.32 & 1.21 \\
\hline Total & 4.04 & .55 \\
\hline
\end{tabular}

* Reversed scoring was employed for the items 3, 9, and 13 in the questionnaire since they are negatively worded questions.

Table 2 shows EFL pre-service teachers' attitudes toward the development of proper pronunciation skills in the target language. The results indicated that preservice English teachers had positive attitudes toward pronunciation. It seems that participants agreed upon the importance of pronunciation and perceive pronunciation as a vital component of language learning and teaching. A careful look at the items individually portrays significant findings regarding phonological issues in language teaching. Participants believed that attaining a native-like accent is highly important and item 12 indicates that they expressed a desire to sound like a native speaker when speaking in the target language. This result shows the connection between their attitudes toward their own accent and classroom practices such that they believed 
teachers should pay more attention to proper pronunciation in classroom practices for promoting the attainment of a native-like accent. Item 6 supports this conclusion since participants strongly agreed that one of their personal goals is to acquire proper pronunciation to pass as a near-native speaker of the target language.

On the other hand, one question in this area referred to participants' attitudes toward communication. Item 8 asked pre-service EFL teachers to rank whether communication is more important than native-like accent. The results of this item displayed that majority of the participants found communication more important than sounding like a native speaker, which prioritizes pronunciation for efficient communication. Nevertheless, more respondents care much about native-like accent. A paradox can be seen when examining the results of items 3 and 4 in the table above. On the one hand, item 3 addresses students' feelings of helplessness, showing that most of the participants believed their pronunciation will never be good.

Besides, item 4 on the inventory revealed that the respondents strongly agreed that they can improve their pronunciation skills. What is striking in the table above is that although participants found good pronunciation important, they did not consider it as a vital aspect of language instruction as other skills such as grammar and vocabulary. Results of item 13 displayed how other students' perceptions of participants' L2 accent influence the desire to practice L2 accent in the classroom. Participants believed that they avoid practicing phonological aspects because of the fear of negative evaluation by their peers in the classroom. In general, participants recognized that native-like accent and proper pronunciation are crucial and essential. They also emphasized language teaching practices including teaching of proper pronunciation.

\section{Results of pre-/Post-Tests}

Paired Samples t-Test was performed to find out if there was a significant difference between the pre-tests and post-tests scores of the EFL students. The results were shown in Table 3. 
Table 3. Paired Samples t-test Results for Pronunciation Scores of the Pre-test and Post-test of Pre-service Teachers

\begin{tabular}{|c|c|c|c|c|c|c|c|}
\hline Dimensions & Test & $\mathbf{N}$ & Mean & SD & Df & $\mathrm{T}$ & $\mathbf{P}$ \\
\hline \multirow[t]{2}{*}{ Vowels } & Pre-test & 86 & 2.25 & .71 & 85 & -12.397 & .000 \\
\hline & Post-test & 86 & 2.83 & .65 & & & \\
\hline \multirow{2}{*}{ Consonants } & Pre-test & 86 & 2.29 & .72 & \multirow{2}{*}{85} & \multirow{2}{*}{-11.684} & \multirow{2}{*}{.000} \\
\hline & Post-test & 86 & 2.91 & 6.3 & & & \\
\hline \multirow{2}{*}{ Intonation } & Pre-test & 86 & 1.85 & .70 & \multirow{2}{*}{85} & \multirow{2}{*}{-11.963} & \multirow{2}{*}{.000} \\
\hline & Post-test & 86 & 2.42 & .61 & & & \\
\hline \multirow{2}{*}{ Word Stress } & Pre-test & 86 & 2.09 & .62 & \multirow{2}{*}{85} & \multirow{2}{*}{-12.142} & \multirow{2}{*}{.000} \\
\hline & Post-test & 86 & 2.67 & .59 & & & \\
\hline \multirow{2}{*}{ Comprehensibility } & Pre-test & 86 & 2.31 & .74 & \multirow{2}{*}{85} & \multirow{2}{*}{-13.555} & \multirow{2}{*}{.000} \\
\hline & Post-test & 86 & 3.01 & .76 & & & \\
\hline \multirow{2}{*}{ Total } & Pre-test & 86 & 2.16 & .61 & \multirow{2}{*}{85} & \multirow{2}{*}{-17.654} & \multirow{2}{*}{.000} \\
\hline & Post-test & 86 & 2.77 & .57 & & & \\
\hline
\end{tabular}

According to the results shown in Table 3, the ratings of pre-service teachers' reading aloud performances in pre-tests and post-tests displayed a significant difference in overall mean of all the participants' pronunciation competency $(t($ total $)=-17,654 ; \mathrm{p}<0,05)$. This means that after the pre-service language teachers received pronunciation instruction, they showed highly significant improvement in overall pronunciation skills.

Given the results of the categories of the rubric individually, it can be seen that there is a statistically significant difference between the ratings of each category in pre-test and post-test, which means that pre-service language teachers improved significantly in articulation of vowels, consonants, word-stress, intonation. Likewise, the results revealed a significant difference for comprehensibility between pre-tests and post-test ratings ( $($ comprehensibility) $=-13,555 ; \mathrm{p}<0,05)$, which means that the pre-service English language teachers also displayed highly significant improvement in their comprehensibility. 


\section{Discussion and Conclusion}

The study grants significant insights into how pre-service EFL learners perceive pronunciation and pronunciation instruction contributes to pronunciation skills. First, it revealed that EFL pre-service teachers had generally positive attitudes toward pronunciation and its teaching. This viewpoint suggests that pre-service EFL teachers seem to be open to the belief that proper pronunciation should be emphasized in language classrooms. This finding appears to comply with that of Counselman (2010) who referred that the participants of his study are concerned about their pronunciation and they believed they can develop their pronunciation through instruction and practice, which shows similarity to the participants' beliefs in this study.

In this study, the highest mean scores indicate that sounding like a native speaker is valuable for pre-service EFL teachers. This finding seems to run counter to that of Kang (2010). The findings in her study showed that only a small number of participants sought to be native-like speakers of the target language. This means that participants mostly preferred being intelligible when speaking in the target language. However, the findings of the study conducted by Coşkun (2011) were very consistent with those of the present study. Coşkun (2011) asserted that the participants in his study agreed on the belief that English language teaching in classroom environment, especially for the purpose of attaining native-like pronunciation, is considered very significant. Similarly, concerning the relationship between the desire to learn pronunciation and pronunciation development, Elliot (1993) suggested an important finding which reveals that students' attitudes are remarkably effective factors in the acquisition of pronunciation of target language. Students are inclined to have better pronunciation of target language if they are more concerned about their pronunciation.

To provide a summary of the discussion about pre-service English language teachers' attitudes toward pronunciation and pronunciation teaching, it can be commented that poor pronunciation skills lead to misunderstanding and distraction in communication as well as being marked or divergent. The participants generally displayed positive attitudes toward pronunciation component in language teaching. Such positive attitudes can be explained by the fact that when language learners can practice the target language with correct pronunciation, they enhance their willingness to communicate. Therefore, pronunciation should be integrated into general language instruction, pronunciation knowledge is necessary to make language users process and comprehend other speakers' speech easily.

The analysis of pre-test and post-test revealed that pre-service EFL teachers improved significantly their phonological skills following the pronunciation training. A number of studies can be provided from the relevant literature supporting that pronunciation skills and comprehensibility can raise through explicit pronunciation instruction as stated in this study. (Derwing and Munro, 2005; Gordon \& Darcy, 2016; 
Jeske, 2012; Kennedy \& Trofimovic, 2010; Lepore, 2014; Venkatagiri \& Levis, 2007; Yoshida, 2010; Zamora, 2015). For example, Jeske (2012) conducted a study to provide evidence for this issue by teaching the relevant vowels to a group of students from two different schools sharing the same L1 and age of first exposure to L2 English but differing in amounts of L2 exposure each week. Results of the study indicated that the students who received larger amounts of L2 pronunciation instruction improved their pronunciation of vowels more than those who were provided less amounts of pronunciation instruction. González Bueno (1994) provided the language learners with a segmental-based pronunciation instruction, and pre-/ post-tests before and after the instruction were performed with the participants. The comparison of the results of the pre-test and post-test showed that there was a significant difference between pre- and post-test in the experimental group while the control group showed no improvement in target sounds, which supports the results of the present study.

The positive impacts of explicit phonological instruction on the students' comprehensibility were also worth mentioning in the discussion of the overall effects of pronunciation training on language learners' speaking skills. The present study indicates that after receiving pronunciation instruction, the students have had more comprehensible speech. Saito (2011) provided similar results maintaining that explicit pronunciation instruction has significant positive effects on comprehensibility. Venkatagiri and Levis (2007) provided support to the same notion based on the findings of their study which summarized that speech comprehensibility was significantly improved due to the greater amount of explicit pronunciation instruction. The results of the present study are notable, this is because they demand a stronger part of pronunciation training including segmental and suprasegmental features in language classrooms to provide the overall pronunciation skills and comprehensibility.

This study raises certain implications for pronunciation teaching. First, more classroom-relevant research should be carried out on pronunciation to establish the most efficient ways of teaching it and to identify the factors that contribute to it. It is likely that proper pronunciation is the paramount concern for language learners and many teachers are not aware of the significance of pronunciation for intelligible communication and social identity. For this reason, it can be suggested that language teachers should resort to the empirical evidence in the creation of pronunciation syllabi rather than relying on their own intuitions. Of more significance are the learners' considerable exposure to certain pronunciation aspects, their motivation for learning a particular pronunciation norm, and creating opportunities for them to notice the importance of pronunciation. Ideally, teacher training programs need to provide language teachers with adequate background to help them diagnose their students' pronunciation needs and problems and interpret research findings to establish their applicability for pronunciation teaching. 


\section{Limitations}

The current study had some limitations of which important reason was perhaps the inventory of the instruction. Though it has been often argued that pronunciation instruction should not be confined to segmental level, suprasegmental features are more important in terms of intelligibility. However, since L2 teachers may be less effective in teaching of L2 pronunciation, the researchers can be a constraint for ideal pronunciation instruction. Another limitation is related to the longtitudinal observation of the instruction effectiveness. Despite 14-week instruction this study did not measure the pronunciation improvement in the long term. This can be a research question for further research. The third limitation is related to research design selection, that is, to observe a cause and relationship, experimental design is needed to reach more reliable results. However, due to formal educational requirements, using more rigorous experimental groups (i.e. control vs. treatment groups) would be unethical and unfeasible in an L2 classroom. For this reason, the current study had to adopt a quasi-experimental design. A further study can be conducted with a sample of different groups who are not in officially educational positions such as academics, private course takers and businesspersons. 


\section{References}

Alastuey, M. C. B. (2013). Synchronous-voice computer-mediated communication: Effects on pronunciation. Computer Assisted Language Instruction Consortium Journal, 28(1), 1-20. Retrieved from http://www.jstor.org/stable/pdf/ calicojournal.28.1.1.pdf

https://doi.org/10.11139/cj.28.1.1-20

Arrieta, M. (2017). Teacher and Student Perceptions of World Englishes (WE) Pronunciations in two US Settings (MSc. Thesis, Portland State University). https://doi.org/10.15760/etd.5309

Baddeley, A. (2012). Working memory: Theories, models, and controversies. Annual review of psychology, 63, 1-29.

https://doi.org/10.1146/annurev-psych-120710-100422

Baran-Lucarz, M. (2012). Individual learner differences and accuracy in foreign language pronunciation. In M. Pawlak (Ed.), New perspectives on individual differences in language learning and teaching (pp. 120-133). Berlin and Heidelberg: Springer.

https://doi.org/10.1007/978-3-642-20850-8_18

Campbell, D. T., \& Stanley, J. C. (2015). Experimental and quasi-experimental designs for research. Ravenio Books.

Camus-Oyarzun, P. (2016). The effects of pronunciation instruction on the production of second language Spanish: A classroom study (Doctoral dissertation). Retrieved from ProQuest Dissertations \& Theses Global. (UMI No: 10249027)

Chiba, K. (2012). A pilot study on the effectiveness of pronunciation teaching to EFL learners through focus on forms and focus on form instruction (Doctoral dissertation).Retrieved from ProQuest Dissertations \& Theses Global. (UMI No: 1288376910).

Counselman, D. (2010). Improving pronunciation instruction in the second language classroom (Doctoral Dissertation). Retrieved from ProQuest Dissertations \& Theses Global. (UMI No: 3436059)

Coşkun, A. (2011). Future English Teachers' Attitudes towards EIL Pronunciation. Online Submission, 6(2), 46-68. Retrieved from https://files.eric.ed.gov/fulltext/ ED527146.pdf

Couper, G. (2003). The value of an explicit pronunciation syllabus in ESOL teaching. Prospect, 18(3), 53-70. http://aut.researchgateway.ac.nz/bitstream/ handle/10292/1524/18_3_4_Couper.pdf?sequence=9\&isAllowed=y 
Creswell, J. W. (2014). Research design: Qualitative, quantitative and mixed methods approaches (4th Edition). Thousand Oaks, CA: Sage Publications.

DeKeyser, R. (2003). Implicit and explicit learning. In C. Doughty \& M. Long (Eds.), The handbook of second language acquisition (pp. 313-349). Oxford, UK: Blackwell.

Derwing, T. M., \& Munro, M. J. (1997). Accent, intelligibility, and comprehensibility: Evidence from four L1s. Studies in second language acquisition, 19(1), 1-16. https://doi.org/10.1017/S0272263197001010

Derwing, T., \& Munro, M. (2005). Second Language Accent and Pronunciation Teaching: A Research-Based Approach. TESOL Quarterly, 39(3), 379-397. https://doi.org/10.2307/3588486

Derwing, T. M., \& Munro, M. J. (2015). Pronunciation fundamentals: Evidence- based perspectives for L2 teaching and research. Amsterdam: John Benjamins. https://doi.org/10.1075/1llt.42

Derwing, T. M., Munro, M. J., Foote, J. A., Waugh, E., \& Fleming, J. (2014). Opening the window on comprehensible pronunciation after 19 years: A workplace training study. Language Learning, 64(3), 526-548.

https://doi.org/10.1111/lang.12053

Dörnyei, Z. (2006). Individual differences in second language acquisition. AILA Review, 19(1), 42-68.

https://doi.org/10.1075/aila.19.05dor

Ducate, L., \& Lomicka, L. (2009). Podcasting: An effective tool for honing language students' pronunciation?. Language Learning \& Technology, 13(3), 66-86. Retrieved from https://scholarcommons.sc.edu/cgi/viewcontent. cgi? article $=1000 \&$ context=ling_facpub

Elias, L. J. (2000). Teaching the pronunciation of spelling patterns in an integrated ESL curriculum (MSc. Thesis). Retrieved from ProQuest Dissertations \& Theses Global. (230801027).

Elliott, A.R. (1993). Biological and Pedagogical Variables in the Acquisition of native and Near Native Phonological Skills in Spanish as a Foreign language (Doctoral dissertation). Retrieved from ProQuest Dissertations \& Theses Global. (UMI No: 9404406)

Elliott, A. R. (1995). Foreign language phonology: Field independence, attitude, and the success of formal instruction in Spanish pronunciation. The modern language journal, 79(4),530-542.

https://doi.org/10.1111/j.1540-4781.1995.tb05456.x 
Fayer, J. M., \& Krasinski, E. (1995). Perception of hesitation in nonnative speech. Bilingual Review, 20(2), 114-121 http://www.jstor.org/stable/25745268

Flege, J. E. (2009). Give input a chance! In T. Piske \& M. Young-Scholten (Eds.), Input matters in SLA (pp. 175-190). Bristol, Buffalo and Toronto: Multilingual Matters. https://doi.org/10.21832/9781847691118-012

Gatbonton, E., Trofimovich, P., \& Magid, M. (2005). Learners' Ethnic Group Affiliation and L2 Pronunciation Accuracy: A Sociolinguistic Investigation. TESOL Quarterly, 39(3), 489-511. https://doi.org/10.2307/3588491

Gilakjani, A. P., \& Sabouri, N. B. (2016). How can EFL teachers help EFL learners improve their english pronunciation ?. Journal of Language Teaching and Research, 7(5), 967-972. https://doi.org/10.17507/jltr.0705.18

González-Bueno, M. (1994). Effects of formal instruction on the improvement in the pronunciation of Spanish stops by second language learners: Changes in voice onset time in initial stops/p, tk/and/b, d, g/ (Doctoral dissertation). Retrived from ProQuest Dissertations \& Theses Global. (UMI No: 9504216)

Gordon, J., \& Darcy, I. (2016). The development of comprehensible speech in L2 learners. Journal of Second Language Pronunciation, 2(1), 56-92.

https://doi.org/10.1075/jslp.2.1.03gor

Harris, D. F. (2002). The effects of training on the pronunciation of mandarin chinese speakers (Doctoral dissertation). Retrieved from ProQuest Dissertations \& Theses Global. (UMI No: 304806053).

Hinofotis, F., \& Bailey, K. (1980). American undergraduate reactions to the communication skills for foreign teaching assistants. In J. Fisher, M. Clarke, \& J. Schacter (Eds.), On TESOL '80: Building bridges (pp. 120-133). Washington, DC: TESOL.

Huensch, A., \& Thompson, A. S. (2017). Contextualizing attitudes toward pronunciation: Foreign language learners in the United States. Foreign language annals, 50(2), 410-432. https://doi.org/10.1111/flan.12259

Huthaily, K. Y. (2008). Second language instruction with phonological knowledge: Teaching Arabic to speakers of English (Doctoral dissertation). Retrieved from ProQuest Dissertations \& Theses Global. (UMI No: 193736656).

Jeske, A. (2016). The development of English vowels by native Spanish speakers (Doctoral dissertation, University of Pitssburgh). Retrieved from http://dscholarship.pitt.edu/27722/1/JeskeA_ETD_Dissertation_May9_2.pdf 
Kang, O. (2010). ESL learners' attitudes toward pronunciation instruction. In J. M. Levis \& K. LeVelle (Eds.), Proceedings of the 1st Pronunciation in Second Language Learning and Teaching Conference (pp. 105-118). Ames: Iowa State University.

Kelly, L. G. (1969). 25 centuries of language teaching. Rowley, MA: Newbury House.

Kennedy, S. (2008). Second language learner speech and intelligibility: Instruction and environment in a university setting (Doctoral dissertation). Retrieved from ProQuest Dissertations \& Theses Global. (763281030).

Kennedy, S., \& Trofimovich, P. (2010). Language awareness and second language pronunciation: A classroom study. Language Awareness, 19(3), 171-185. https:// doi.org/10.1080/09658416.2010.486439

Kissling, E. M. (2013). Teaching pronunciation: Is explicit phonetics instruction beneficial for FL learners?. The modern Language Journal, 97(3), 720-744. https://doi.org/10.1111/j.1540-4781.2013.12029.x

Kissling, E. M. (2015). Phonetics instruction improves learners' perception of L2 sounds. Language teaching research, 19(3), 254-275.

https://doi.org/10.1177/1362168814541735

Labov, J., \& Hanau, C. (2011). Chapter Twelve: Pronunciation as Life and Death: Improving the Communication Skills of Non-Native English Speaking Pathologists. In English language and the medical profession: Instructing and assessing the communication skills of international physicians (pp. 261-285). Brill. https://doi.org/10.1163/9781780523859_013

Lepore, C. E. (2014). Developing pronunciation skills at the introductory level: Motivating students through interpersonal audio discussions (Doctoral dissertation). Retrieved from ProQuest Dissertations \& Theses Global. (UMI No: 1658786133).

Levis, J. (2005). Changing contexts and shifting paradigms in pronunciation teaching. TESOL Quarterly, 39, 367-377.

https://doi.org/10.2307/3588485

Long, M. (2015). Second language acquisition and task-based language teaching. Malden, MA \& Oxford, UK: Wiley Blackwell.

Lord, G. (2008). Podcasting communities and second language pronunciation. Foreign Language Annals, 41(2), 364-379. https://doi.org/10.1111/j.1944-9720.2008.tb03297.x 
Ma, R. (2015). The role of pronunciation in speaking test ratings. (Unpublished MSc. thesis). Brigham Young University, Provo, Utah. Retrieved from https:// scholarsarchive.byu.edu/etd/4426/

Moyer, A. (2004). Age, accent and experience in second language acquisition: An integrated approach to critical period inquiry. Clevedon: Multilingual Matters. https://doi.org/10.21832/9781853597190

Munro, M. J., \& Derwing, T. M. (1995). Foreign accent, comprehensibility, and intelligibility in the speech of second language learners. Language Learning, 45(1), 73-97.

https://doi.org/10.1111/j.1467-1770.1995.tb00963.x

Munro, M. J., \& Derwing, T. M. (1999). Foreign accent, comprehensibility, and intelligibility in the speech of second language learners. Language Learning, 49 (1), 285-310. https://doi.org/10.1111/0023-8333.49.s1.8

Munro, M. J., Derwing, T. M., \& Morton, S. L. (2006). The mutual intelligibility of L2 speech. Studies in Second Language Acquisition, 28(1), 111-131.

https://doi.org/10.1017/S0272263106060049

Roccamo, A. (2015). Teaching Pronunciation in Just Ten Minutes a Day: A Method for Pronunciation Instruction in First-Semester German Language Classrooms. Die Unterrichtspraxis /Teaching German, 48(1), 59-83.

https://doi.org/10.1111/tger.10181

Saito, K. (2011). Examining the role of explicit phonetic instruction in native-like and comprehensible pronunciation development: An instructed SLA approach to L2 phonology. Language awareness, 20(1), 45-59.

https://doi.org/10.1080/09658416.2010.540326

Saito, K. (2012). Effects of instruction on L2 pronunciation development: A synthesis of 15 quasi-experimental intervention studies. Tesol Quarterly, 46(4), 842-854.

https://doi.org/10.1002/tesq.67

Saito, K. (2015a). Experience effects on the development of late second language learners' oral proficiency. Language Learning, 65(3), 563-595.

https://doi.org/10.1111/lang.12120

Saito, K. (2015b). The role of age of acquisition in late second language oral proficiency attainment. Studies in Second Language Acquisition, 37(4), 713-743.

https://doi.org/10.1017/S0272263115000248 
Sardegna, V. G., Lee, J., \& Kusey, C. (2018). Self-efficacy, attitudes, and choice of strategies for English pronunciation learning. Language Learning, 68(1), 83-114. https://doi.org/10.1111/lang.12263

Sifakis, N. C. (2014). Teaching pronunciation in the post-EFL era: Lessons from ELF and implications for teacher education. In J. D. D. M. Agudo, (Ed.), English as a Foreign Language Teacher Education: Current perspectives and challenges. (pp. 127-146). Amsterdam and New York: Rodopi.

https://doi.org/10.1163/9789401210485_009

Singleton, D. (1995). Introduction: A critical look at the critical period hypothesis in second language acquisition research. In D. Singleton \& Z. Lengyel (Eds.), The age factor in second language acquisition (pp. 1-29). Clevedon, UK: Multilingual Matters.

Thomson, R. I., \& Derwing, T. M. (2014). The effectiveness of L2 pronunciation instruction: A narrative review. Applied Linguistics, 36(3), 326-344.

https://doi.org/10.1093/applin/amu076

Tlazalo Tejeda, A. C., \& Basurto Santos, N. M. (2014). Pronunciation instruction and students' practice to develop their confidence in EFL oral skills. Profile Issues in Teachers Professional Development, 16(2), 151-170.

https://doi.org/10.15446/profile.v16n2.46146

Tsunemoto, A., \& McDonough, K. (2020). Exploring Japanese EFL Learners' Attitudes Toward English Pronunciation and its Relationship to Perceived Accentedness. Language and Speech. 1-11. https://doi.org/10.1177/0023830919900372

Uchida, Y., \& Sugimoto, J. (2019). Non-native English teachers' confidence in their own pronunciation and attitudes towards teaching: A questionnaire survey in Japan. International Journal of Applied Linguistics. https://doi.org/10.1111/ijal.12253

Venkatagiri, H. S., \& Levis, J. M. (2007). Phonological awareness and speech comprehensibility: An exploratory study. Language awareness, 16(4), 263-277. https://doi.org/10.2167/la417.0

Wilner, L. K. (2007). Communication skills training programs for doctors. Academic Internal Medicine Insight, 5(3), 14-15. http://www.im.org/p/cm/ld/fid=209

Yagiz, O. (2018). EFL Language Teachers' Cognitions and Observed Classroom Practices about L2 Pronunciation: The Context of Turkey. Novitas-ROYAL (Research on Youth and Language), 12(2), 187-204. Retrieved from https://files. eric.ed.gov/fulltext/EJ1195280.pdf 
Yoshida, K. (2010). Effects of oral practice on pronunciation: Focusing on word accentuation (Doctoral dissertation) Retrieved from ProQuest Dissertations \& Theses Global. (UMI No: 3702794)

Zamora, J. E. G. (2015). Teaching and learning L2 pronunciation: A closer look at classroom and extra-classroom factors in the development of comprehensibility in ESL learners (Doctoral dissertation). Retrieved from ProQuest Dissertations \& Theses Global. (UMI No: 3702794)

This study was adopted from the first author's Ph.D. dissertation in 2018. TUBITAK (The Scientific and Technological Research Council of Turkey) supported this Ph.D. dissertation financially through its scholarship 2211-National Graduate Scholarship Programme.

\section{Authors}

${ }^{\star}$ Canan Aksakallı is an assistant professor at Atatürk University, Department of Translation and Interpretation in Turkey. Her research interests are second language acquisition and all aspects of L2 speech, especially accent and intelligible speech. She also teaches at the undergraduate level in the field of translation.

ORCID: https://orcid.org/0000-0003-0685-0789

Oktay Yağız Asst. Prof. works at Atatürk University, School of Education, Department of English Teaching in Turkey. His research interests are English academic writing, educational research and pronunciation based studies. He also teaches at undergraduate and graduate levels in the fields mentioned above.

ORCID: https://orcid.org/0000-0001-7076-7774

How to reference this article: Aksakallı, C., \& YağıZ, O. (2020). The Pre-Service EFL Teachers' Development of Phonological Processing and Evaluation of Their Attitudes toward Pronunciation. GIST - Education and Learning Research Journal, 20, 7-31. https://doi. org/10.26817/16925777.712 